EISSN: 2706-7955 ISSN: 2077-4605

DOI: 10.36632/mejar/2021.10.1.13

Journal homepage: www.curresweb.com

Pages: 227-237

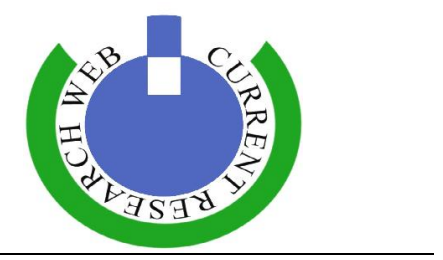

\title{
Plant genetic barcoding of some Legume tree species grown in Egypt
}

\section{Houssam El-Din M.F. El-Wakil ${ }^{1}$, Aly Z. Abdelsalam², Hesham M. Aly ${ }^{3}$, Asma Aboshady², Samar M.A. Rabie ${ }^{1}$, Mohamed E. Hasan ${ }^{4}$ and Nader R. Abdelsalam ${ }^{1}$}

${ }^{1}$ Agricultural Botany Department Faculty of Agriculture, Saba-Basha, Alexandria University, Egypt.

${ }^{2}$ Genetics Department, Faculty of Agriculture, Ain-Shams University, Egypt.

${ }^{3}$ Department of Forestry and Wood Technology, Horticulture Institute, Agriculture Research Center, Antoniadis Botanical Garden, Alexandria 21554, Egypt.

${ }^{4}$ Bioinformatic Department, Genetic Engineering and Biotechnology Research Institute, University of Sadat City, Egypt

\author{
Received: 20 December 2020 Accepted: 10 February $2021 \quad$ Published: 25 February 2021
}

\begin{abstract}
DNA barcoding as tools for rapid species documentation based on DNA sequences. During the current study fifteen species were collected, belonged to family fabacea from Antoniades Garden Alexandria between July 2019 and January $2020 R b c L$ and $m a t K$ of the plastid genomes were used to study the sequence of the nucleotides bases of these genetic materials, alignment the current genetic sequence which obtained from NCBI and CBOL and matched the observed sequence with other in the GeneBank, calculating the differential between the different species of trees using precise genetic coding instead of the phenotypic distinction and finding the evolutionary relationship between the types of these trees. The results showed that the quality of the extracted DNA which detected by using $1 \%$ agarose gel electrophoresis there were no fragmentation was observed in extracted DNA. Also, the extracted DNA was directly used in PCR amplification for the two genes; RbcL (600 bp) and MatK gene (900 bp). The average of nucleotides composition for all the plant species are $\mathrm{A}=27.23 \%, \mathrm{G}=20.86 \%, \mathrm{G}=22.43 \%$ and $\mathrm{T}=29.45 \%$, while the $\mathrm{G}+\mathrm{C}=40.30 \%$ and $\mathrm{A}+\mathrm{T}=56.69 \%$ in a total number 585.26 nucleotides. Also, the data of MatK gene, showed highly similiters percentage ranged from 95.63 to 99.77 for all the studied species with others in gene bank. For instance, Cassia fistula was identical with the same species on GenBank (99.77\%), while Delonix regia showed high similarities with Delonix regia, Delonix boiviniana voucher Bruneau (99.54). The average of nucleotides composition for all the plant species are $\mathrm{A}=37.30 \%, \mathrm{G}=15.11 \%, \mathrm{C}=16.84 \%$ and $\mathrm{T}=30.75 \%$, while the $\mathrm{G}+\mathrm{C}=31.95 \%$ and $\mathrm{A}+\mathrm{T}=68.05 \%$ in a total number 833 nucleotides. Regarding to $R b c L$ gene, there are high significant homogeneity between the tested species as follow: Tipuana tipu with Schotia brachypetala, Parkinsonia aculeata, Leucaena leucocephala, Delonix regia and Dalbergia sissoo with P-values were 0.010, 0.014, 0.030, 0.000 and 0.024. While other significant was observed between Schotia brachypetala Parkinsonia aculeata with Erythrina humeana by 0.004; Erythrina_humeana with Delonix regia and Cassia javanica by 0.004 and 0.030 and finally, Delonix regia with Cassia fistula by P-values 0.032 . On the other hand, for MatK, there are significant homogeneity between Erythrina_humeana and the fowling species were Sophora secundiflora, Tipuana tipu, Senna surattensis, Schotia brachypetala, Parkinsonia aculeata, Leucaena leucocephala and Acacia saligna (0.000, 0.000, 0.004, 0.000, 0.000, 0.000 and 0.000). while Tipuana tipu with Enterolobium_contortisiliquum by (0.036). Also, Erythrina_humeana showed significant homogeneity with the species Enterolobium contortisiliquum, Dichrostachys cinerea, Delonix regia, Dalbergia sissoo, Cassia javanica, Albizia lebbek and Cassia fistula.
\end{abstract}

Keywords: DNA sequences, $r b c L$ and $m a t K$ genome, Legume, fabacea, gene Bank 


\section{Introduction}

DNA barcoding as tools for rapid species documentation based on DNA sequences, share an emphasis on huge scale genetic data which give the accurate difference among species. DNA barcode consists of a standarized short sequence of DNA ( 400 to $800 \mathrm{bp}$ ) should be easily created for all species on the planet has been stablished to stimulate the creations of data base of documented reference DNA sequences to serve as a library for undefined taxa. DNA barcode is one of the advanced molecular markers-based method that classify target plant species in short period. The purpose of DNA barcodes is nucleotide sequence-based documentation of multiple plant species with accuracy and is one of the widely accepted technology (Group et al., 2009) DNA barcodes help to discover new species and to identify cryptic species (Ward et al., 2008) and might facilitate biodiversity valuations and minor the cost and time requirement of traditional taxonomic biodiversity research (Gaston and O'Neill 2004; Hebert et al., 2004; Pauls et al., 2010).

Becker et al. (2011) reported that DNA barcodes are a perfect established technique and has been showed to bring substantial benefits to different application such as species interactions, biodiversity valuation and plant conservation (Valentini et al., 2009 and Francis et al., 2010), in addition its supplement to traditional morphology-based taxonomy (Hebert and Gregory 2005; Packer et al., 2009 and Wang et al., 2016). Also, DNA barcodes can show the distribution of intra and intra- specific variations based on the distance and similarity (Hebert et al., 2003; Meyer and Paulay 2005).

Sarvananda (2018) reviewed that DNA barcoding is the identical system for fast and accurate to identify the species especially for the ecological system that using short DNA sequence. They renamed the short DNA sequence from the standard region of genome as marker. Also, they classified the genes to, CO1 cytochrome c oxidase 1 used for animals; matK and $r b c L$ used for plants and (ITS) Internal Transcribed Spacer using for fungus. Tahir et al. (2018) tested six DNA barcodes, notably ITS2, matK,rbcL a,ITS2+matK,ITS2+rbcL a, matK+rbcL a and ITS2+matK+rbcL a, for their ability to identify frequently consumed but geographically isolated medicinal species of Fabaceae and Poaceae native to the Cholistan Desert. The results showed that the comparison of six barcode regions showed that ITS2 had the highest number of variables.

Marizzi et al. (2018) reviewed the fact that DNA barcoding is an essential tool for research and science education. They said that this technology enables rapid and accurate genetic diversity using only a minimal amount of tissue samples taken from any organism at any stage of development. They discovered that DNA barcoding allows citizens scientists to make preliminary taxonomic identifications and to make a contribution. da Silva et al. (2018) reported that Fabaceae is among the most diverse family in the world, recognized for its ecological and economic potential; divided into the following sub-families (Caesalpinioideae, Cercidoideae, Detarioideae, Dialioideae, Duparquetioideae). They discussed various species, divided into 14 genera and four subfamilies. Macêdo et al. (2018) reported that Fabaceae is one of the major groups of ethnopharmacological significance. The most versatile Fabaceae species and the agreement of use between informants were evaluated in the Chapada do Araripe Savanna. Semi-structured interviews were conducted with 126 informants, adopting a snowball method and using a structured protocol. Therefore, this proposed research is scrutinized to barcode some legume trees plants distributed in Egypt based on morphological and DNA barcode studies using $r b c L$ and $m a t K$.

\section{Materials and methods}

The current work was carried out in The Faculty of Agriculture, Agricultural Botany Department, Saba Basha, Alexandria University, Alexandria, Egypt during the period of 2019 to 2021 to study accurate taxonomical identification of some Legume tree species grown in Egypt by applying plant genetic barcoding. During the current study fifteen species were collected (Table 1), belonged to family fabacea from Antoniades Garden's between July 2019 and January 2020. The morphological characters were detected based on previous publications, besides photographed all the plant species by the own authors. 
Table 1: Scientific name for studied species

\begin{tabular}{cl}
\hline No. & Scientific name \\
\hline $\mathbf{1}$ & Cassia fistula \\
$\mathbf{3}$ & Cassia javinca \\
$\mathbf{4}$ & Albizia lebbek \\
$\mathbf{5}$ & Delonix regia \\
$\mathbf{6}$ & Senna surattensis \\
$\mathbf{7}$ & Parkinsonia aculeata \\
$\mathbf{8}$ & Schotia brachypetala \\
$\mathbf{9}$ & Tipuana tipu \\
$\mathbf{1 0}$ & Erythrina humeana \\
$\mathbf{1 1}$ & Sophora secundiflora \\
$\mathbf{1 2}$ & Leucaena leucocephala \\
$\mathbf{1 3}$ & Enterolobium contortisiliquum \\
$\mathbf{1 4}$ & Dichrostachys cinerea \\
$\mathbf{1 5}$ & Acacia saligna \\
\hline
\end{tabular}

\subsection{Molecular Genetic analysis (plant barcoding):}

\subsubsection{DNA extraction}

Genomic DNA was extracted from fresh leaves tissue using i-genomic plant DNA extraction Mini kit @ iNtron Biotechnology according to the protocol associated with the Plant Genomic DNA Kit (iNtRON Bio Co., South Korea) according to the manufacturer descriptions as following:

\subsubsection{PCR amplification}

PCR amplification was conducted by using Applied Biosystems ${ }^{\circledR}$ ProFlex ${ }^{\mathrm{TM}}$ PCR System (Figure 3). The PCR amplification conditions were optimized for the all reactions by using extracted DNA in a total volume reaction of $25 \mu 1$ containing 12.50 $\mu 1$ of Master Mix.1.25 $\mu 1$ of each Primer (forward and reverse), $2 \mu \mathrm{l}$ of DNA template and de-ionized water up to $25 \mu$ l. Two universal primers (matK $-R b c L$ ) were designed by using the Basic Local Search tool (BLAST) were designed by Primer3 program shown in Table 1 and synthesized by willow fort company Info@willowfort.co.uk at 11/12/2018 The primers were used in PCR amplification with modification in PCR conditions (the temperatures and the times for PCR steps).

Table 2: primer sequence and GC\% used in the current study

\begin{tabular}{llcc}
\hline Name & Primer sequence (5'-- $\left.\mathbf{3}^{\prime}\right)$ & Tm & GC\% \\
\hline \multirow{2}{*}{$\boldsymbol{R} \boldsymbol{b} \boldsymbol{L} \boldsymbol{L}$} & F: ATGTCACCACAAACAGAGACTAAAGC & 57.2 & 42 \\
& R: GTAAAATCAAGTCCACCRCG & 52.8 & 48 \\
\multirow{2}{*}{$\boldsymbol{M a t} \boldsymbol{K}$} & F: CGTACAGTACTTTTGTGTTTACGAG & 53.9 & 40 \\
& R: ACCCAGTCCATCTGGAAATCTTGGTTC & 60.4 & 48 \\
\hline
\end{tabular}

\subsubsection{Primer preparation and dilution}

Primers obtained in lyophilized state were centrifuged at $1000 \mathrm{rpm}$ for 5 minutes, deionized nuclease-free dd $\mathrm{H}_{2} \mathrm{O}$ was added by recommended volume described in the primers sheet to form a concentration of $100 \mathrm{pmol}$, vortexed thoroughly until complete resuspension then primers dilution applied to form a regular PCR working concentration of 25 pmol.

\subsubsection{DNA bands elution from the agarose gel}

DNA bands of MT-CO1 gene were eluted from the agarose gel through elution kit from @iNtRON Biotechnology, Inc. Korea. For elution, $40 * 1$ of PCR product from each sample was loaded in $0.8 \%$ agarose medium. The elution steps were achieved as described in the Kit manual.

\subsubsection{Sequence analysis:}

The data analysis was done for the one grouped dataset. This set includes all the plant species of Fabaceae for which the sequences are available in GenBank to find the interspecies and intergeneric variation. Fabaceae species sequences of $m a t K$ and $r b c L$ were received from NCBI in fasta format. 
Multiple sequence alignments of the $m a t K$ and $r b c L$ gene were conducted from different species using the PROMALS server (Pei and Grishin, 2007), Clustal Omega server (Sievers et al., 2011), the BIOEDIT software (Hall, 20110, Clustal X and MEGA-x (Stecher et al., 2020) which are offline software that performs optimum alignment for sequence to extract the conserved regions.

\subsubsection{Molecular evolutionary and phylogenetic analysis}

The evolutionary history was inferred using the Neighbor Joining method. The process of finding a phylogenetic tree using maximum likelihood involves finding the topology and branch lengths of the tree that will give us the greatest probability of observing amino acid sequences in our data. So, for Phylogenetic analysis Mafft server (Katoh et al., 2015), Clustal Omega server and MEGA-x software was used. The sequence data was analyzed by neighbor-joining method and Unweighed Pair Group Mean Average (UPGMA) using MEGA. Distances were calculated using DNADIST program of PHYLIP. Bootstrapping and decay analysis were performed by NJ plot. Parsimony analysis and various clades were determined by MEGA.

\section{Results and Discussion}

The quality of the extracted DNA was detected by using 1\% agarose gel electrophoresis as observed in Figure 1 for samples. The results indicated that there is no fragmentation was observed in extracted DNA. The quantity of extracted DNA samples was determined by using Nano drop Spectrophotometer and the concentration ranged from $30-50 \mathrm{ng} / \mu \mathrm{l}$. The extracted DNA was directly used in PCR amplification as found in Figure 2 for the first gene RbcL (600 bp) and in Figure 3 for MatK gene (900 bp).

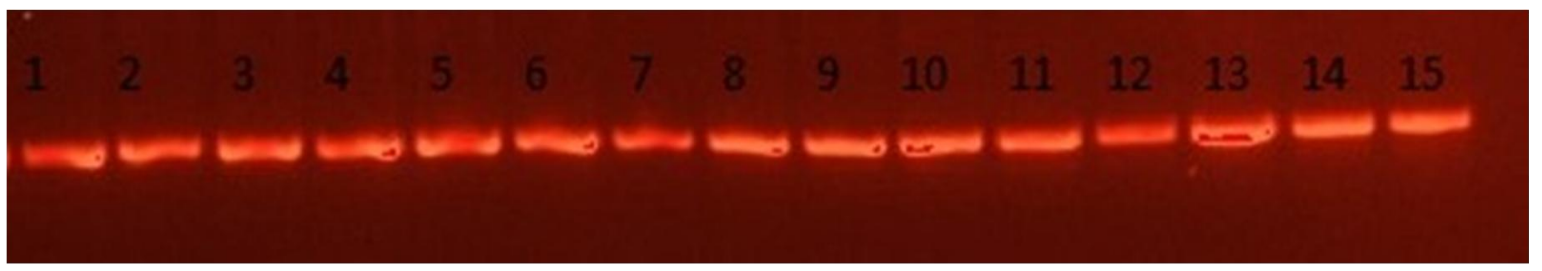

Fig. 1: Agarose gel electrophoresis for extracted DNA from samples (1) Cassia fistula, (2) Cassia javinca, (3) Albizia lebbek, (4) Delonix regia, (5) Senna surattensis, (6) Parkinsonia aculeata, (7) Schotia brachypetala, (8) Tipuana tipu, (9) Erythrina humeana, (10) Sophora secundiflora, (11) Leucaena leucocephala, (12) Enterolobium contortisiliquum, (13) Dichrostachys cinerea, (14) Acacia saligna and (15) Dalbergia sissoo

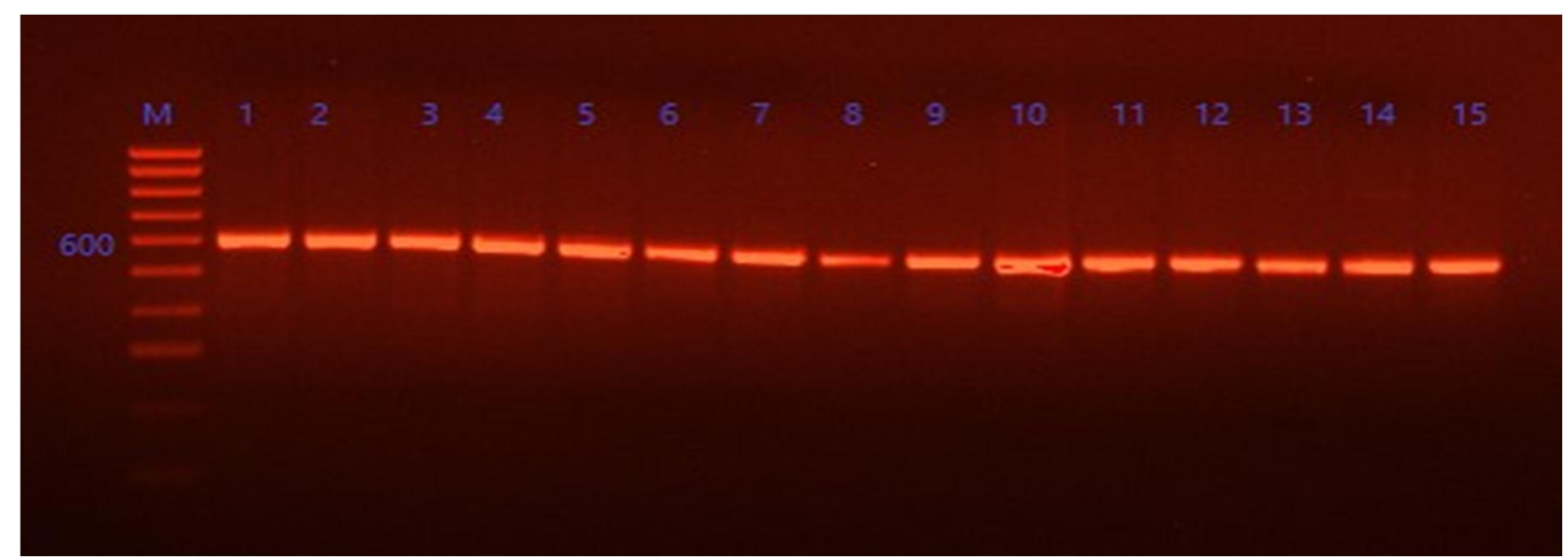

Fig. 2: Agarose gel electrophoresis for amplified samples by using the primer $R b c L$ for the amples (1) Cassia fistula, (2) Cassia javinca, (3) Albizia lebbek, (4) Delonix regia, (5) Senna surattensis, (6) Parkinsonia aculeata, (7) Schotia brachypetala, (8) Tipuana tipu, (9) Erythrina humeana, (10) Sophora secundiflora, (11) Leucaena leucocephala, (12) Enterolobium contortisiliquum, (13) Dichrostachys cinerea, (14) Acacia saligna and (15) Dalbergia sissoo 


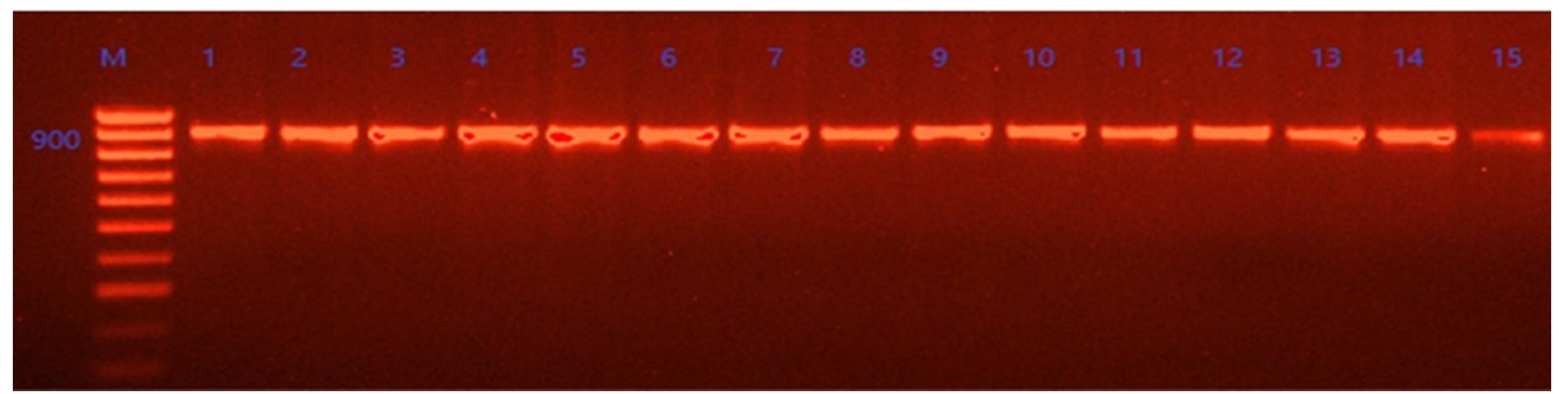

Fig. 3: Agarose gel electrophoresis for amplified samples by using the primer MatK for the amples (1) Cassia fistula, (2) Cassia javinca, (3) Albizia lebbek, (4) Delonix regia, (5) Senna surattensis, (6) Parkinsonia aculeata, (7) Schotia brachypetala, (8) Tipuana tipu, (9) Erythrina humeana, (10) Sophora secundiflora, (11) Leucaena leucocephala, (12) Enterolobium contortisiliquum, (13) Dichrostachys cinerea, (14) Acacia saligna and (15) Dalbergia sissoo

\subsection{Phylogenetic analysis of chloroplast $R b c L$ gene of some legume tree species grown in Egypt.}

The data in Table (3) presented the similarity percentage which calculated by the BLAST and the phylogenetic affinity based on the plant sequencing using $R b c L$ gene, which showed highly similiters percentage ranged from 97.81 to 100 for all the studied species with others in gene bank. For instance, the collected sample Cassia fistula was identical with the same species on GenBank (100\%), while Cassia javinca showed high similarities with Cassia javanica subsp. Nodosa and Erythrophleum fordii in percentage 96.38 to $97.81 \%$ (Table, 3) and the other matching is presented in the Table 3.

Table 3: Database search match for similarities and phylogenetic relationship using $r b c L$ gene sequences for legume tree species grown in Egypt used in study.

\begin{tabular}{|c|c|c|c|c|c|}
\hline ID & Morphological identification & BLAST search match & $\begin{array}{c}\text { Positions } \\
\text { in the final } \\
\text { dataset }\end{array}$ & $\begin{array}{c}\text { BLAST } \\
\text { similarity } \\
(\%)\end{array}$ & $\begin{array}{l}\text { Phylogenetic } \\
\text { affinity }\end{array}$ \\
\hline 1 & Cassia fistula & Cassia fistula & 585 & 100 & Cassia fistula \\
\hline 2 & Cassia javinca & $\begin{array}{l}\text { Cassia javanica subsp. } \\
\text { Nodosa } \\
\text { Erythrophleum fordii }\end{array}$ & 442 & $\begin{array}{l}96.38 \\
97.81\end{array}$ & Cassia javinca \\
\hline 3 & Albizia lebbek & Albizia lebbek & 581 & 99.83 & Albizia sp \\
\hline 4 & Delonix regia & Delonix regia & 586 & 99.66 & Delonix $s p$ \\
\hline 5 & Senna surattensis & $\begin{array}{l}\text { Senna sulfurea } \\
\text { Balsamocarpon } \\
\text { brevifolium } \\
\text { Moullava spicata } \\
\text { Senna sp. } \\
\end{array}$ & 571 & $\begin{array}{l}99.49 \\
99.03 \\
98.64 \\
98.63\end{array}$ & Senna $s p$ \\
\hline 6 & Parkinsonia aculeata & Parkinsonia aculeata & 578 & 100 & Parkinsonia $s p$ \\
\hline 7 & Schotia brachypetala & Schotia brachypetala & 565 & 100 & Schotia $s p$ \\
\hline 8 & Tipuana tipu & Tipuana tipu & 586 & 99.83 & Tipuana sp \\
\hline 9 & Erythrina humeana & Erythrina humeana & 597 & 100 & Erythrina $s p$ \\
\hline 10 & Sophora secundiflora & Sophora secundiflora & 570 & 100 & Sophora sp \\
\hline 11 & Leucaena leucocephala & Leucaena leucocephala & 583 & 99.82 & Leucaena $s p$ \\
\hline 12 & Enterolobium contortisiliquum & $\begin{array}{l}\text { Enterolobium } \\
\text { contortisiliquum }\end{array}$ & 478 & 99.37 & Enterolobium $s p$ \\
\hline 13 & Dichrostachys cinerea & Dichrostachys cinerea & 570 & 98.42 & Dichrostachys $s p$ \\
\hline 14 & Acacia saligna & $\begin{array}{l}\text { Acacia saligna } \\
\text { Falcataria moluccana } \\
\text { Pararchidendron } \\
\text { pruinosum }\end{array}$ & 587 & $\begin{array}{l}99.83 \\
99.83 \\
99.83\end{array}$ & Acacia saligna $s p$ \\
\hline 15 & Dalbergia sissoo & Dalbergia sissoo & 594 & 99.83 & Dalbergia $s p$ \\
\hline
\end{tabular}

The data in Table 3 showed the positions in the final dataset for all the tested samples which ranged from 422 in Cassia javinca to 597 in Erythrina humeana. While the data in Table (4) showed the nucleotides content in all studied species and the whole numbers of nucleotides. The average for all number of nucleotides is 582.26 nucleotides and each species showed range of 500 nucleotides using the $R b c L$ gene. 
For instance, in the first species Cassia fistula, the nucleotides composition was $\mathrm{A}=27.34 \%$, $\mathrm{G}=20.79 \%, \mathrm{G}=22.28 \%$ and $\mathrm{T}=29.59 \%$, while the $\mathrm{G}+\mathrm{C}=43.07 \%$ and $\mathrm{A}+\mathrm{T}=56.93 \%$ in atal number 585 nucleotides. The other nucleotides composition for other plant species found in Table 4. The average of nucleotides composition for all the plant species are $\mathrm{A}=27.23 \%, \mathrm{G}=20.86 \%, \mathrm{G}=22.43 \%$ and $\mathrm{T}=29.45 \%$, while the $\mathrm{G}+\mathrm{C}=40.30 \%$ and $\mathrm{A}+\mathrm{T}=56.69 \%$ in a total number 585.26 nucleotides

The phylogenetic tree in Figure (4) and Table 5 divided into two main cluster at $0.015 \%$ includes Enterolobium contortisiliquum in separate cluster and all other plant species in the second cluster. The second cluster divided into two main subcluster $0.013 \%$, the first one includes two plant species are Albizia lebbek and Acacia saligna (0.001\%) and the other species in the second subcluster expect Leucaena leucocephala was in separate branch. The analysis of DNA polymorphisms is a powerful approach to understand the evolutionary process and to establish the functional significance of genomic regions (Begun et al., 2007; Nielsen, 2005; Rosenberg and Nordborg, 2002).

Table 4: Percent of nucleotides composition of $R b c L$ sequences of legume tree species grown in Egypt by BioEdit sequence Alignment Editor version 7.2.5 (12/11/2013)

\begin{tabular}{lccccccc}
\hline Samples & A & C & G & T & G+C & A+T & Total \\
\hline Cassia fistula & 27.34 & 20.79 & 22.28 & 29.59 & 43.07 & 56.93 & 585 \\
Cassia javinca & 26.97 & 21.35 & 22.47 & 29.21 & 43.82 & 56.18 & 595 \\
Albizia lebbek & 27.34 & 20.97 & 22.85 & 28.85 & 43.82 & 56.18 & 581 \\
Delonix regia & 26.78 & 21.54 & 23.03 & 28.65 & 44.57 & 55.43 & 586 \\
Senna surattensis & 27.15 & 20.79 & 22.47 & 29.59 & 43.26 & 56.74 & 571 \\
Parkinsonia aculeata & 26.78 & 20.97 & 23.03 & 29.21 & 44.01 & 55.99 & 578 \\
Schotia brachypetala & 26.56 & 21.35 & 22.85 & 29.21 & 44.19 & 55.81 & 565 \\
Tipuana tipu & 28.28 & 20.41 & 21.35 & 29.96 & 41.76 & 58.24 & 588 \\
Erythrina humeana & 28.28 & 19.66 & 21.72 & 30.34 & 41.39 & 58.61 & 598 \\
Sophora secundiflora & 27.90 & 20.79 & 21.91 & 29.40 & 42.70 & 57.30 & 570 \\
Leucaena leucocephala & 26.59 & 20.41 & 23.03 & 29.96 & 43.45 & 56.55 & 583 \\
Enterolobium contortisiliquum & 25.66 & 21.54 & 22.85 & 29.96 & 44.38 & 55.62 & 583 \\
Dichrostachys cinerea & 27.72 & 20.79 & 22.10 & 29.40 & 42.88 & 57.12 & 570 \\
Acacia saligna & 27.34 & 20.79 & 22.85 & 29.03 & 43.63 & 56.37 & 587 \\
Dalbergia sissoo & 27.90 & 20.97 & 21.72 & 29.40 & 42.70 & 57.30 & 594 \\
\hline Average & 27.23 & 20.86 & 22.43 & 29.45 & 43.30 & 56.69 & 582.26 \\
\hline
\end{tabular}

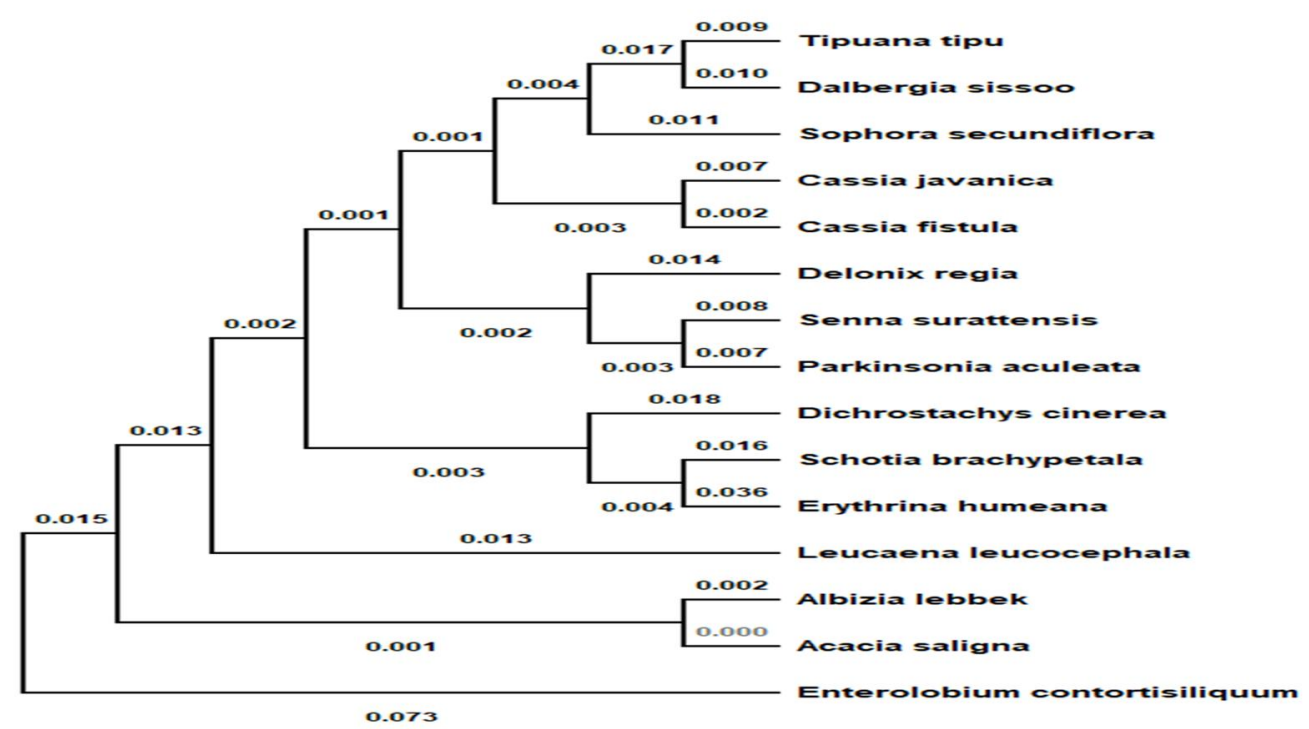

Fig. 4: phylogentic tree of legume tree species grown in Egypt in this study using $R b c L$ gene 
Table 5: Evolutionary divergence estimation between $R b c L$ sequences of legume tree species grown

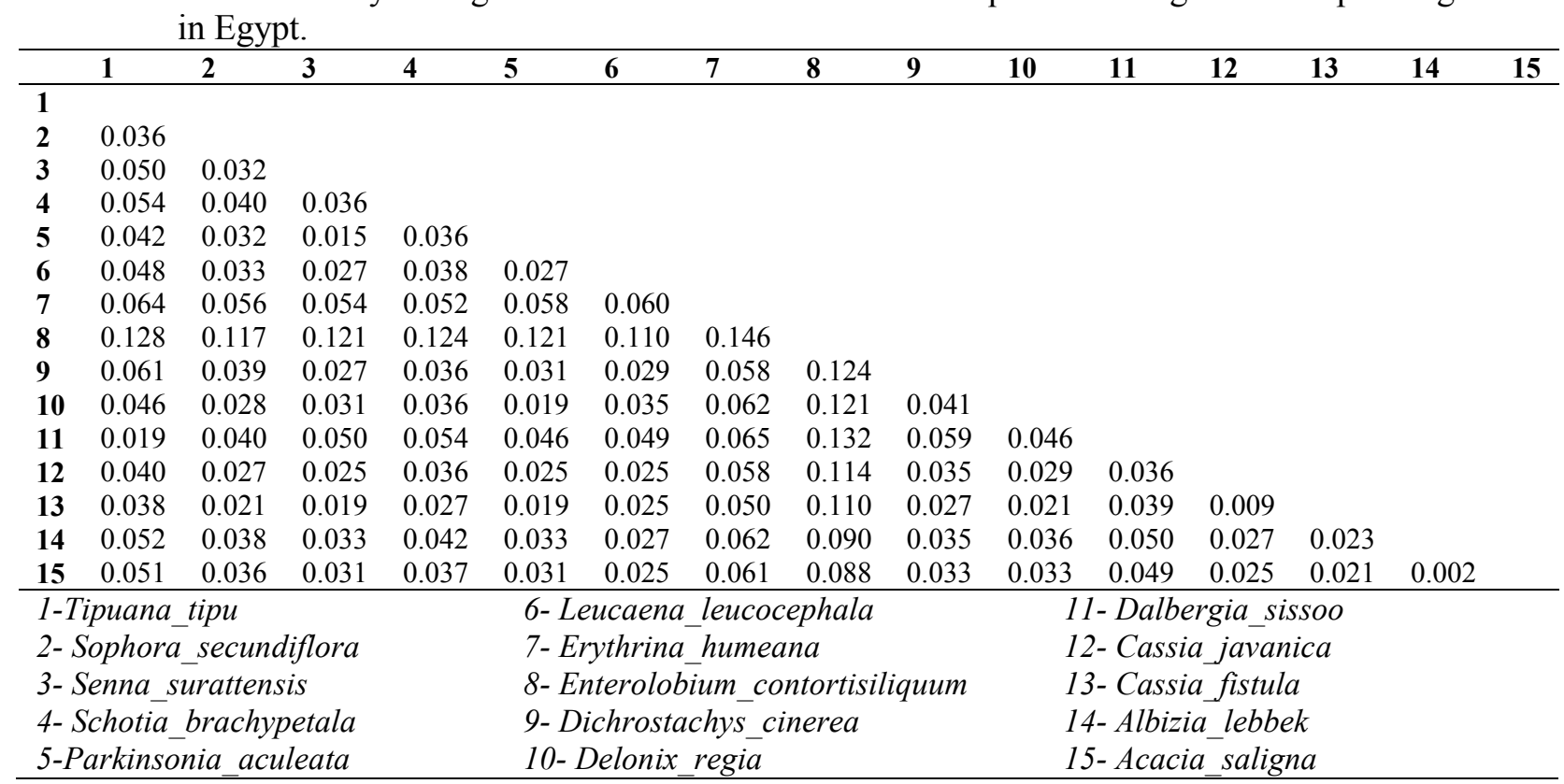

3.2. Phylogenetic analysis of chloroplast matK gene of some legume tree species grown in Egypt. The data in Table (6) presented the similarity percentage which calculated by the BLAST and the phylogenetic affinity based on the plant sequencing using MatK gene, which showed highly similiters percentage ranged from 95.63 to 99.77 for all the studied species with others in gene bank. For instance, the collected sample Cassia fistula was identical with the same species on GenBank (99.77\%), while Delonix regia showed high similarities with Delonix regia, Delonix boiviniana voucher Bruneau (99.54\%). (Table, 10) and the other matching is presented in the Table 6.

The data in Table 6 showed the positions in the final dataset for all the tested samples which ranged from 763 in Dalbergia sissoo to 870 in Acacia saligna. While the data in Table (7) showed the nucleotides content in all studied species and the whole numbers of nucleotides. The average for all number of nucleotides is 833 nucleotides and each species showed range of 800 nucleotides using the MatK gene. For instance, in the first species Cassia fistula, the nucleotides composition was A $=36.98 \%$, $\mathrm{G}=16.88 \%, \mathrm{C}=15.81 \%$ and $\mathrm{T}=30.32 \%$, while the $\mathrm{G}+\mathrm{C}=32.70 \%$ and $\mathrm{A}+\mathrm{T}=67.30 \%$ in a total number 854 nucleotides.

The other nucleotides composition for other plant species found in Table 7. The average of nucleotides composition for all the plant species are $\mathrm{A}=37.30 \%, \mathrm{G}=15.11 \%, \mathrm{C}=16.84 \%$ and $\mathrm{T}=30.75 \%$, while the $\mathrm{G}+\mathrm{C}=31.95 \%$ and $\mathrm{A}+\mathrm{T}=68.05 \%$ in a total number 833 nucleotides

The phylogenetic tree in Figure (5) divided into two main cluster at $0.012 \%$ includes Erythrina humeana in separate cluster and all other plant species in the second cluster.

The second cluster divided into two main subcluster $0.016 \%$, the first one includes three plant species are Sophora_secundiflora, Tipuana_tipu and Dalbergia_sissoo $(0.005 \%)$ and the other species in the second subcluster expect Schotia_brachypetala was in separate branch $(0.066 \%)$. The analysis of DNA polymorphisms is a powerful approach to understand the evolutionary process and to establish the functional significance of genomic regions (Begun et al., 2007; Nielsen, 2005; Rosenberg and Nordborg, 2002). 
Table 6: Database search match for similarities and phylogenetic relationship using MatK gene sequences for some legume tree species grown in Egypt used in study.

\begin{tabular}{|c|c|c|c|c|c|}
\hline ID & $\begin{array}{l}\text { Morphological } \\
\text { identification }\end{array}$ & BLAST search match & $\begin{array}{l}\text { Positions in } \\
\text { the final } \\
\text { dataset }\end{array}$ & $\begin{array}{l}\text { BLAST } \\
\text { similarity (\%) }\end{array}$ & $\begin{array}{l}\text { Phylogenetic } \\
\text { affinity }\end{array}$ \\
\hline 1 & Cassia fistula & Cassia fistula & 823 & 99.77 & Cassia fistula \\
\hline 2 & Cassia javinca & Cassia javinca & 845 & 99.52 & Cassia javinca \\
\hline 3 & Albizia lebbek & Albizia lebbek & 788 & 97.91 & Albizia $s p$ \\
\hline 4 & Delonix regia & $\begin{array}{l}\text { Delonix regia } \\
\text { Delonix boiviniana } \\
\text { voucher Bruneau }\end{array}$ & 864 & $\begin{array}{l}99.54 \\
99.54\end{array}$ & Delonix sp \\
\hline 5 & Senna surattensis & Senna surattensis & 842 & 98.58 & Senna sp \\
\hline 6 & $\begin{array}{l}\text { Parkinsonia } \\
\text { aculeata }\end{array}$ & Parkinsonia aculeata & 832 & 95.63 & Parkinsonia $s p$ \\
\hline 7 & $\begin{array}{l}\text { Schotia } \\
\text { brachypetala }\end{array}$ & $\begin{array}{l}\text { Schotia brachypetala } \\
\text { Schotia afra }\end{array}$ & 828 & $\begin{array}{l}99.30 \\
99.30\end{array}$ & Schotia $s p$ \\
\hline 8 & Tipuana tipu & Tipuana tipu & 824 & 98.91 & Tipuana sp \\
\hline 9 & $\begin{array}{l}\text { Erythrina } \\
\text { humeana }\end{array}$ & Erythrina humeana & 781 & 98.72 & Erythrina $s p$ \\
\hline 10 & $\begin{array}{l}\text { Sophora } \\
\text { secundiflora }\end{array}$ & Sophora secundiflora & 855 & 99.62 & Sophora sp \\
\hline 11 & $\begin{array}{l}\text { Leucaena } \\
\text { leucocephala }\end{array}$ & Leucaena leucocephala & 820 & 99.16 & Leucaena $s p$ \\
\hline 12 & $\begin{array}{l}\text { Enterolobium } \\
\text { contortisiliquum }\end{array}$ & $\begin{array}{l}\text { Enterolobium } \\
\text { contortisiliquum } \\
\text { Enterolobium } \\
\text { cyclocarpum }\end{array}$ & 856 & $\begin{array}{l}98.35 \\
98.35\end{array}$ & Enterolobium $s p$ \\
\hline 13 & $\begin{array}{l}\text { Dichrostachys } \\
\text { cinerea }\end{array}$ & $\begin{array}{l}\text { Dichrostachys cinerea } \\
\text { Dichrostachys spicata }\end{array}$ & 866 & $\begin{array}{l}99.29 \\
99.41 \\
\end{array}$ & Dichrostachys sp \\
\hline 14 & Acacia saligna & Acacia saligna & 870 & 98.28 & Acacia saligna $s p$ \\
\hline 15 & Dalbergia sissoo & Dalbergia sissoo & 763 & 99.08 & Dalbergia $s p$ \\
\hline
\end{tabular}

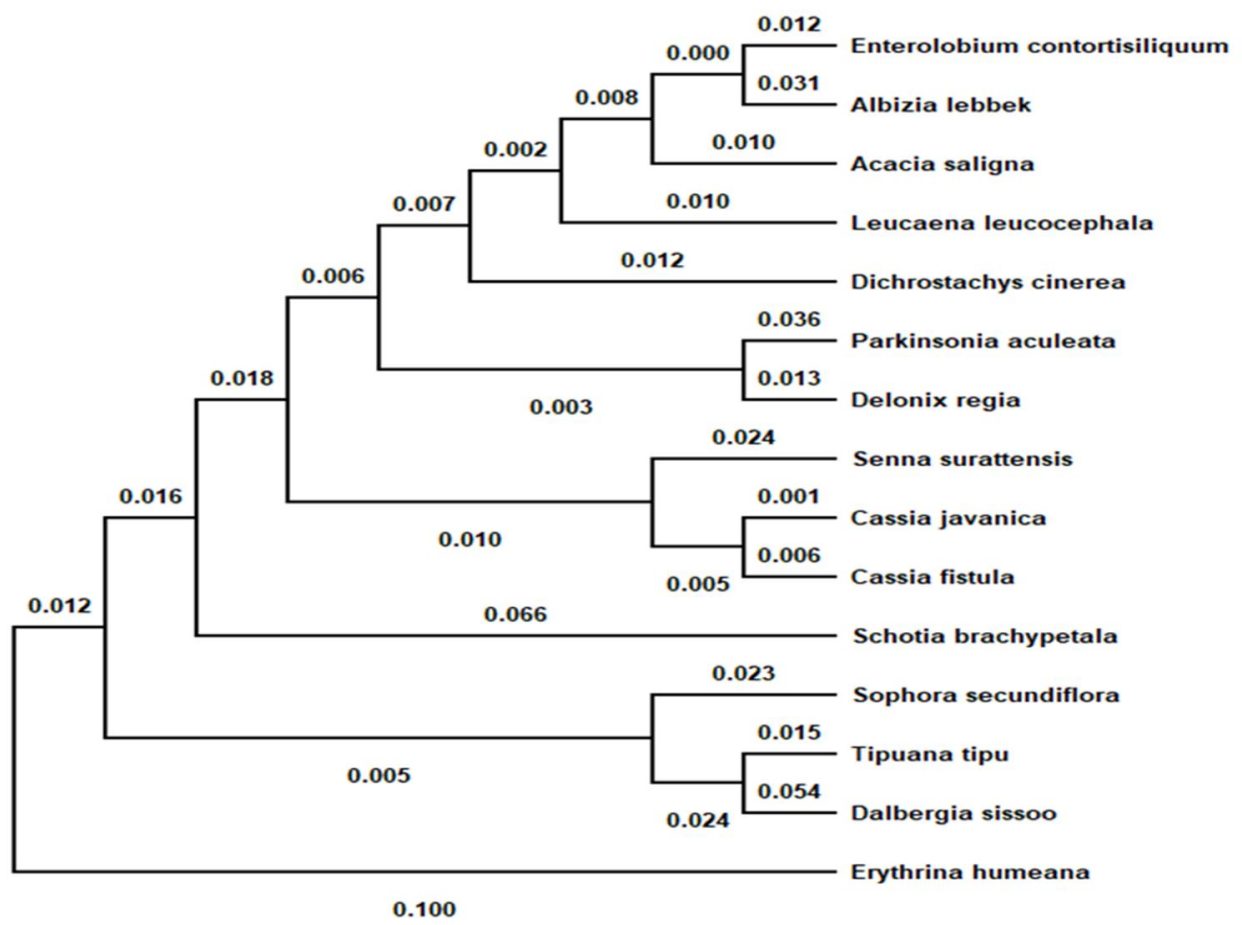

Fig. 5: phylogentic tree of the used species in this study using MatK gene 
Table 7: Evolutionary divergence estimation between $M a t K$ sequences of samples.

\begin{tabular}{|c|c|c|c|c|c|c|c|c|c|c|c|c|c|c|c|}
\hline & 1 & 2 & 3 & 4 & 5 & 6 & 7 & 8 & 9 & 10 & 11 & 12 & 13 & 14 & 15 \\
\hline \multicolumn{16}{|l|}{1} \\
\hline 2 & 0.065 & & & & & & & & & & & & & & \\
\hline 3 & 0.097 & 0.109 & & & & & & & & & & & & & \\
\hline 4 & 0.108 & 0.131 & 0.118 & & & & & & & & & & & & \\
\hline 5 & 0.107 & 0.124 & 0.078 & 0.127 & & & & & & & & & & & \\
\hline 6 & 0.083 & 0.097 & 0.057 & 0.110 & 0.060 & & & & & & & & & & \\
\hline 7 & 0.094 & 0.111 & 0.068 & 0.120 & 0.069 & 0.028 & & & & & & & & & \\
\hline 8 & 0.139 & 0.157 & 0.183 & 0.193 & 0.191 & 0.169 & 0.178 & & & & & & & & \\
\hline 9 & 0.093 & 0.111 & 0.070 & 0.120 & 0.072 & 0.030 & 0.023 & 0.179 & & & & & & & \\
\hline 10 & 0.086 & 0.101 & 0.057 & 0.112 & 0.061 & 0.023 & 0.032 & 0.166 & 0.034 & & & & & & \\
\hline 11 & 0.084 & 0.102 & 0.057 & 0.105 & 0.048 & 0.034 & 0.043 & 0.169 & 0.048 & 0.031 & & & & & \\
\hline 12 & 0.099 & 0.069 & 0.150 & 0.163 & 0.158 & 0.138 & 0.151 & 0.196 & 0.149 & 0.141 & 0.142 & & & & \\
\hline 13 & 0.081 & 0.095 & 0.030 & 0.094 & 0.061 & 0.041 & 0.053 & 0.169 & 0.055 & 0.043 & 0.036 & 0.135 & & & \\
\hline 14 & 0.086 & 0.100 & 0.034 & 0.097 & 0.067 & 0.044 & 0.056 & 0.171 & 0.059 & 0.047 & 0.041 & 0.137 & 0.007 & & \\
\hline 15 & 0.113 & 0.126 & 0.091 & 0.139 & 0.076 & 0.049 & 0.042 & 0.193 & 0.043 & 0.053 & 0.067 & 0.168 & 0.070 & 0.077 & \\
\hline \multicolumn{5}{|c|}{ 1-Sophora_secundiflora } & \multicolumn{6}{|c|}{ 6-Leucaena_leucocephala } & \multicolumn{5}{|c|}{ 11- Delonix regia } \\
\hline \multicolumn{5}{|c|}{ 2-Tipuana_tipu } & \multicolumn{5}{|c|}{ 7-Acacia_saligna } & \multicolumn{4}{|c|}{ 12-Dalbergia_sissoo } & & \\
\hline \multicolumn{5}{|c|}{ 3-Senna_surattensis } & \multicolumn{5}{|c|}{ 8-Erythrina_humeana } & \multicolumn{4}{|c|}{ 13-Cassia_javanica } & & \\
\hline \multicolumn{5}{|c|}{ 4-Schotia_brachypetala } & \multicolumn{5}{|c|}{ 9-Enterolobium_contortisiliquum } & \multicolumn{4}{|c|}{ 14-Cassia_fistula } & & \\
\hline \multicolumn{5}{|c|}{ 5-Parkinsonia aculeata } & \multicolumn{5}{|c|}{ 10-Dichrostachys cinerea } & \multicolumn{4}{|c|}{ 15-Albizia lebbek } & & \\
\hline
\end{tabular}

Homogeneity of Substitution Patterns Between Sequences based on RbcL and MatK genes.

The data in Table 8 and 8 showed the homogeneity between the tested species based on the two selected genes. The probability of rejecting the null hypothesis that sequences have evolved with the same pattern of substitution, as judged from the extent of differences in base composition biases between sequences according to the method of Kumar and Gadagkar (2001) using 500 replicates to estimate the $P$-values which are shown above the diagonal. $P$-values smaller than 0.05 are considered significant and marked with yellow highlights in Table 8 and 9.

Regarding to the data in Table 8 for $R b c L$ gene, there are high significant homogeneity between the tested species as follow: Tipuana tipu with Schotia brachypetala, Parkinsonia aculeata, Leucaena leucocephala, Delonix regia and Dalbergia sissoo with P-values were 0.010, 0.014, 0.030, 0.000 and 0.024. while other significant was observed between Schotia brachypetala Parkinsonia aculeata with Erythrina humeana by 0.004; Erythrina_humeana with Delonix regia and Cassia javanica by 0.004 and 0.030 and finally, Delonix regia with Cassia fistula by P-values 0.032.

Table 8: The Homogeneity Test of Substitution Patterns Between Sequences using RbcL gene.

\begin{tabular}{llllllllllllllll}
\hline & $\mathbf{1}$ & $\mathbf{2}$ & $\mathbf{3}$ & $\mathbf{4}$ & $\mathbf{5}$ & $\mathbf{6}$ & $\mathbf{7}$ & $\mathbf{8}$ & $\mathbf{9}$ & $\mathbf{1 0}$ & $\mathbf{1 1}$ & $\mathbf{1 2}$ & $\mathbf{1 3}$ & $\mathbf{1 4}$ & $\mathbf{1 5}$ \\
\hline $\mathbf{1}$ & & 0.000 & 0.026 & 0.122 & 0.118 & 0.105 & 0.000 & 0.161 & 0.000 & 0.170 & 0.006 & 0.079 & 0.017 & 0.075 & 0.062 \\
$\mathbf{2}$ & 1.000 & & 0.000 & 0.039 & 0.037 & 0.060 & 0.008 & 0.075 & 0.000 & 0.069 & 0.000 & 0.015 & 0.000 & 0.004 & 0.000 \\
$\mathbf{3}$ & 0.186 & 1.000 & & 0.000 & 0.0019 & 0.000 & 0.045 & 0.000 & 0.000 & 0.021 & 0.000 & 0.000 & 0.000 & 0.000 & 0.000 \\
$\mathbf{4}$ & 0.010 & 0.120 & 1.000 & & 0.000 & 0.000 & 0.169 & 0.000 & 0.023 & 0.000 & 0.032 & 0.000 & 0.008 & 0.000 & 0.000 \\
$\mathbf{5}$ & 0.014 & 0.082 & 0.360 & 1.000 & & 0.000 & 0.129 & 0.000 & 0.019 & 0.000 & 0.036 & 0.000 & 0.009 & 0.000 & 0.000 \\
$\mathbf{6}$ & 0.030 & 0.032 & 1.000 & 1.000 & 1.000 & & 0.081 & 0.000 & 0.039 & 0.047 & 0.062 & 0.026 & 0.011 & 0.030 & 0.017 \\
$\mathbf{7}$ & 1.000 & 0.376 & 0.112 & 0.004 & 0.034 & 0.076 & & 0.184 & 0.013 & 0.215 & 0.011 & 0.114 & 0.032 & 0.103 & 0.079 \\
$\mathbf{8}$ & 0.076 & 0.186 & 1.000 & 1.000 & 1.000 & 1.000 & 0.072 & & 0.039 & 0.000 & 0.066 & 0.000 & 0.002 & 0.034 & 0.032 \\
$\mathbf{9}$ & 1.000 & 1.000 & 1.000 & 0.192 & 0.174 & 0.090 & 0.304 & 0.260 & & 0.037 & 0.00 & 0.000 & 0.000 & 0.000 & 0.000 \\
$\mathbf{1 0}$ & 0.000 & 0.016 & 0.154 & 1.000 & 1.000 & 0.064 & 0.004 & 1.000 & 0.148 & & 0.058 & 0.000 & 0.039 & 0.000 & 0.000 \\
$\mathbf{1 1}$ & 0.302 & 1.000 & 1.000 & 0.206 & 0.150 & 0.064 & 0.306 & 0.222 & 1.000 & 0.094 & & 0.007 & 0.000 & 0.002 & 0.000 \\
$\mathbf{1 2}$ & 0.024 & 0.164 & 1.000 & 1.000 & 1.000 & 0.100 & 0.030 & 1.000 & 1.000 & 1.000 & 0.298 & & 0.008 & 0.000 & 0.000 \\
$\mathbf{1 3}$ & 0.192 & 1.000 & 1.000 & 0.302 & 0.228 & 0.238 & 0.230 & 0.402 & 1.000 & 0.032 & 1.000 & 0.166 \\
$\mathbf{1 4}$ & 0.068 & 0.362 & 1.000 & 1.000 & 1.000 & 0.120 & 0052 & 0.250 & 1.000 & 1.000 & 0.380 & 1.000 & 0.418 & 0.002 & 0.000 \\
$\mathbf{1 5}$ & 0.064 & 1.000 & 1.000 & 1.000 & 1.000 & 0.214 & 0.080 & 0.274 & 1.000 & 1.000 & 1.000 & 1.000 & 1.000 & 1.000 & 0.000 \\
\hline
\end{tabular}

1- Tipuana_tipu, 2-Sophora_secundiflora, 3-Senna_surattensis, 4-Schotia_brachypetala, 5-Parkinsonia_aculeata,

6-Leucaena_leucocephala, 7-Erythrina_humeana, 8-Enterolobium_contortisiliquum, 9-Dichrostachys_cinerea,

10-Delonix_regia, 11-Dalbergia_sissoo, 12-Cassia_javanica, 13-Cassia_fistula, 14-Albizia_lebbek and

15-Acacia_saligna

On the other hand, the data in Table 9 for the next gene $M a t K$, there are significant homogeneity between Erythrina_humeana and the fowling species were Sophora secundiflora, Tipuana tipu, Senna surattensis, Schotia brachypetala, Parkinsonia aculeata, Leucaena leucocephala and Acacia saligna $(0.000,0.000,0.004,0.000,0.000,0.000$ and 0.000). while Tipuana tipu with Enterolobium_contortisiliquum by (0.036). Also, Erythrina_humeana showed significant homogeneity 
with the species Enterolobium contortisiliquum, Dichrostachys cinerea, Delonix regia, Dalbergia sissoo, Cassia javanica, Albizia lebbek and Cassia fistula (see Table 9).

Table 9: Test of the Homogeneity of Substitution Patterns Between Sequences matK gene

\begin{tabular}{llllllllllllllll}
\hline & $\mathbf{1}$ & $\mathbf{2}$ & $\mathbf{3}$ & $\mathbf{4}$ & $\mathbf{5}$ & $\mathbf{6}$ & $\mathbf{7}$ & $\mathbf{8}$ & $\mathbf{9}$ & $\mathbf{1 0}$ & $\mathbf{1 1}$ & $\mathbf{1 2}$ & $\mathbf{1 3}$ & $\mathbf{1 4}$ & $\mathbf{1 5}$ \\
\hline $\mathbf{1}$ & & 0.000 & 0.000 & 0.000 & 0.024 & 0.000 & 0.000 & 1.220 & 0.058 & 0.000 & 0.000 & 0.000 & 0.000 & 0.000 & 0.000 \\
$\mathbf{2}$ & 1.000 & & 0.005 & 0.004 & 0.109 & 0.027 & 0.027 & 0.857 & 0.191 & 0.000 & 0.000 & 0.000 & 0.000 & 0.000 & 0.005 \\
$\mathbf{3}$ & 1.000 & 0.412 & & 0.057 & 0.000 & 0.000 & 0.000 & 0.950 & 0.024 & 0.001 & 0.000 & 0.000 & 0.029 & 0.000 & 0.015 \\
$\mathbf{4}$ & 1.000 & 0.366 & 0.234 & & 0.124 & 0.000 & 0.000 & 1.603 & 0.048 & 0.005 & 0.000 & 0.000 & 0.000 & 0.000 & 0.001 \\
$\mathbf{5}$ & 0.300 & 0.122 & 1.000 & 0.104 & & 0.037 & 0.000 & 1.157 & 0.012 & 0.100 & 0.045 & 0.109 & 0.031 & 0.058 & 0.002 \\
$\mathbf{6}$ & 1.000 & 0.270 & 1.000 & 1.000 & 0.170 & & 0.0000 & 1.365 & 0.018 & 0.036 & 0.000 & 0.012 & 0.012 & 0.000 & 0.008 \\
$\mathbf{7}$ & 1.000 & 0.248 & 1.000 & 1.000 & 1.000 & 1.000 & & 1.278 & 0.014 & 0.037 & 0.000 & 0.015 & 0.000 & 0.000 & 0.000 \\
$\mathbf{8}$ & 0.000 & 0.000 & 0.004 & 0.000 & 0.000 & 0.000 & 0.000 & & 1.577 & 0.886 & 1.203 & 0.787 & 1.257 & 1.442 & 1.270 \\
$\mathbf{9}$ & 0.194 & 0.036 & 0.300 & 0.234 & 0.340 & 0.162 & 0.228 & 0.000 & & 0.134 & 0.072 & 0.189 & 0.099 & 0.030 & 0.076 \\
$\mathbf{1 0}$ & 1.000 & 1.000 & 0.406 & 0.360 & 0.048 & 0.054 & 0.092 & 0.000 & 0.002 & & 0.018 & 0.000 & 0.049 & 0.019 & 0.057 \\
$\mathbf{1 1}$ & 1.000 & 1.000 & 1.000 & 1.000 & 0.110 & 1.000 & 1.000 & 0.000 & 0.064 & 0.196 & & 0.000 & 0.000 & 0.000 & 0.000 \\
$\mathbf{1 2}$ & 1.000 & 1.000 & 1.000 & 1.000 & 0.166 & 0.326 & 0.356 & 0.002 & 0.082 & 1.000 & 1.000 & \\
$\mathbf{1 3}$ & 1.000 & 1.000 & 0.120 & 1.000 & 0.200 & 0.314 & 1.000 & 0.000 & 0.034 & 0.116 & 1.000 & 1.000 \\
$\mathbf{1 4}$ & 1.000 & 1.000 & 1.000 & 1.000 & 0.130 & 1.000 & 1.000 & 0.000 & 0.182 & 0.264 & 1.000 & 1.000 & 1.000 \\
$\mathbf{1 5}$ & 1.000 & 0.390 & 0.230 & 0.374 & 0.38 & 0.304 & 1.000 & 0.000 & 0.060 & 0.074 & 1.000 & 1.000 & 1.000 & 1.000 \\
\hline
\end{tabular}

1-Sophora_secundiflora, 2-Tipuana_tipu, 3-Senna_surattensis, 4-Schotia_brachypetala, 5-Parkinsonia_aculeata,

6-Leucaena_leucocephala, 7-Acacia_saligna, 8-Erythrina_humeana, 9-Enterolobium_contortisiliquum,

10-Dichrostachys_cinerea, 11-Delonix_regia, 12-Dalbergia_sissoo, 13-Cassia_javanica, 14-Albizia_lebbek

15-Cassia_fistula

\section{References}

Becker, S., R. Hanner, and D. Steinke, 2011. Five years of FISH-BOL: brief status report. Mitochondrial DNA, 22(sup1): 3-9.

Begun, D.J., A.K. Holloway, K. Stevens, L.W. Hillier, Y.P. Poh, M.W. Hahn and C.H. Langley, 2007. Population genomics: whole-genome analysis of polymorphism and divergence in Drosophila simulans. PLoS Biol, 5(11): e310.

Da Silva Gomes, G., G.S. Silva, D.L. dos Santos Silva, R.R. de Oliveira, and G.M. da Conceição, 2018. Botanical Composition of Fabaceae Family in the Brazilian Northeast, Maranhão, Brazil. Asian Journal of Environment and Ecology, 1-10.

Francis, C.M. A.V., Borisenko, N.V. Ivanova, J.L. Eger, B.K. Lim, A. Guillén-Servent, ,.. and P.D. Hebert, 2010. The role of DNA barcodes in understanding and conservation of mammal diversity in Southeast Asia. PloS one, 5(9): e12575.

Gaston, K.J., and M.A. O'Neill, 2004. Automated species identification: why not?. Philosophical Transactions of the Royal Society of London. Series B: Biological Sciences, 359(1444): 655667.

Group, C.P.W., P.M. Hollingsworth, L.L. Forrest, J.L. Spouge, M. Hajibabaei, S. Ratnasingham, ... and D.P. Little, 2009. A DNA barcode for land plants. Proceedings of the National Academy of Sciences, 106(31): 12794-12797.

Hall H., 2001. BioEdit version 5.0.6. North Carolina State University, Department of Microbiology.

Hebert, P.D., and T.R. Gregory, 2005. The promise of DNA barcoding for taxonomy. Systematic Biology, 54(5): 852-859.

Hebert, P.D., A. Cywinska, S.L. Ball, and J.R. Dewaard, 2003. Biological identifications through DNA barcodes. Proceedings of the Royal Society of London. Series B: Biological Sciences, 270(1512): 313-321.

Hebert, P. D., E.H. Penton, J.M. Burns, D.H. Janzen, and W. Hallwachs, 2004. Ten species in one: DNA barcoding reveals cryptic species in the neotropical skipper butterfly Astraptes fulgerator. Proceedings of the National Academy of Sciences, 101(41): 14812-14817.

Hollingsworth, P.M., S.W. Graham and D.P. Little, 2011. Choosing and using a plant DNA barcode. PloS one, 6(5): e19254.

Katoh, Y., S. Nozaki, D. Hartanto, R. Miyano, and K. Nakayama, 2015. Architectures of multisubunit complexes revealed by a visible immunoprecipitation assay using fluorescent fusion proteins. Journal of cell science, 128(12): 2351-2362. 
Kumar, S., and S.R. Gadagkar, 2001. Disparity index: a simple statistic to measure and test the homogeneity of substitution patterns between molecular sequences. Genetics, 158(3): 13211327.

Macêdo, M.J.F., D.A. Ribeiro, M. de Oliveira Santos, D.G. de Macedo, J.G.F. Macedo, B.V. de Almeida, ... and M.M. de Almeida Souza, 2018. Fabaceae medicinal flora with therapeutic potential in Savanna areas in the Chapada do Araripe, Northeastern Brazil. Revista Brasileira de Farmacognosia, 28(6): 738-750.

Marizzi, C., A. Florio, M. Lee, M. Khalfan, C. Ghiban, B. Nash, ... and D.A. Micklos, 2018. DNA barcoding Brooklyn (New York): A first assessment of biodiversity in Marine Park by citizen scientists. PloS one, 13(7): e0199015.

Meyer, C.P., and G. Paulay, 2005. DNA barcoding: error rates based on comprehensive sampling. PLoS biol, 3(12): e422.

Nielsen, R., 2005. Molecular signatures of natural selection. Annu. Rev. Genet., 39: 197-218.

Packer, L., J. Gibbs, C. Sheffield, and R. Hanner, 2009. DNA barcoding and the mediocrity of morphology. Molecular Ecology Resources, 9:42-50.

Pauls, S.U., R.J. Blahnik, X. Zhou, C.T. Wardwell, and R.W. Holzenthal, 2010. DNA barcode data confirm new species and reveal cryptic diversity in Chilean Smicridea (Smicridea)(Trichoptera: Hydropsychidae). Journal of the North American Benthological Society, 29(3): 1058-1074.

Pei, J., and N.V. Grishin, 2007 .PROMALS: towards accurate multiple sequence alignments of distantly related proteins. Bioinformatics, 23(7):802-808.

Rosenberg, N.A., and M. Nordborg, 2002. Genealogical trees, coalescent theory and the analysis of genetic polymorphisms. Nature Reviews Genetics, 3(5): 380-390.

Sarvananda, L., 2018. Short introduction of DNA barcoding. Int. J. Res, 5(4), 673-685.

Sievers, F., A. Wilm, D. Dineen, T. J. Gibson, K. Karplus, W. Li, and D.G. Higgins, 2011. Fast, scalable generation of high-quality protein multiple sequence alignments using Clustal Omega. Molecular systems Biology, 7(1): 539.

Stecher, G., K. Tamura, and S. Kumar, 2020 . Molecular evolutionary genetics analysis (MEGA) for macOS. Molecular Biology and Evolution, 37(4): 1237-1239.

Tahir, A., F. Hussain, N. Ahmed, A. Ghorbani, and A. Jamil, 2018. Assessing universality of DNA barcoding in geographically isolated selected desert medicinal species of Fabaceae and Poaceae. PeerJ, 6: e4499.

Valentini, A., F. Pompanon, and P. Taberlet, 2009. DNA barcoding for ecologists. Trends in Ecology and Evolution, 24(2): 110-117.

Wang, F.H., J.M. Lu, J. Wen, A. Ebihara, and D.Z. Li, 2016. Applying DNA barcodes to identify closely related species of ferns: A case study of the Chinese Adiantum (Pteridaceae). PloS one, 11(9): e0160611.

Ward, R.D., F.O. Costa, B.H. Holmes, and D. Steinke, 2008. DNA barcoding of shared fish species from the North Atlantic and Australasia: minimal divergence for most taxa, but Zeus faber and Lepidopus caudatus each probably constitute two species. Aquatic Biology, 3(1): 71-78. 